\title{
Earnings Management, Enterprise Scale and Enterprise Value- Research Based on Data and Statistical Analysis Tools
}

\author{
Yang Mengxiao ${ }^{1}$ \\ ${ }^{1}$ School of Economics and Management, Beijing Jiaotong University, Beijing, China
}

\begin{abstract}
This paper takes China's A-share listed companies in Shanghai and Shenzhen Stock Exchange from 2012 to 2016 as samples to analyze the impact of earnings management on current and subsequent enterprise value. It is found that real earnings management not only affects the current value, but also damages the long-term value of enterprises continuously. Further research finds that the size of the firm has a moderating effect, that is, the larger the size of the firm, the damage effect of real earnings management on the firm value is mitigated.
\end{abstract}

\section{1 introduction}

As for the impact of earnings management on enterprise value, different scholars have different views and conclusions. Some scholars believe that earnings management will damage the value of enterprises. Some scholars believe that earnings management only affects short-term value and will not do harm to the future value of enterprises. S.Rajgopal et al. (2005) ${ }^{[1]}$ found that enterprises that achieve the earnings forecast target through real earnings management have better future performance, meaning that real earnings management will not have a negative impact on the future value of the enterprise. In addition, there are researches point out that enterprises can retain core employees through earnings management (Gao et al.,2015) ${ }^{[2]}$ and stabilize the capital chain of enterprises. Based on the above viewpoints, this paper empirically tests whether earnings management can affect enterprise value or even its subsequent value by using the data of A-share listed companies in Shanghai and Shenzhen Stock Exchange, and provides references and suggestions for the healthy development of enterprise value maintenance and capital market.

\section{Literature review and hypothesis development}

\subsection{Earnings management and firm value}

Earnings management behavior will cause accounting information distortion, disrupt the effective allocation of market resources, and damage enterprise value. For the long-term value of the enterprise, accrual earnings management behavior only changes the distribution of accounting earnings in each period and does not affect the real cash flow, so it will not affect the long-term decision of the enterprise. But real earnings management through the control of daily business activities to change the trajectory of enterprise operation, can be implemented in the fiscal year does not involve the behavior of accounting treatment problems, so it can avoid the supervision of auditors. Most scholars believe that the real earnings management of enterprises will change the business planning of enterprises, lead to the decline of business performance, and damage the value of enterprises. It can be seen that there is a consensus that real earnings management damages the current value of the enterprise, but there is disagreement on whether it has an impact on the future value of the enterprise. Some scholars, such as A.GUNNY (2010) ${ }^{[3]}$, found that if an enterprise only conducts earnings management occasionally and can return to the strategic track of normal operation under the change of external environment, such behavior will instead promote the improvement of the enterprise's future performance (A.GUNNY,2010) ${ }^{[3]}$. Other scholars hold opposite opinions. Cai Chun et al. (2013) ${ }^{[4]}$ showed that the manipulation of real earnings management would cause abnormal future cash flow and damage the future value of the enterprise. To sum up, this paper proposes the first hypothesis:

H1: earnings management manipulation will damage the current enterprise value, but only real earnings management will damage the future value of the enterprise.

\subsection{The moderating effect of size}

At present, there are two opposite views on the relationship between real earnings management and scale in academic field. One view is that enterprise scale can effectively restrain earnings management behavior because the internal control system of large-scale enterprises will be more effective and can better ensure the reliability of financial information disclosed to the public; large-scale enterprises have higher reputational costs in society, including the reputation of financial information, 
so the cost of earnings management will be higher (M.Cristhian, R. Jory and N. Ngo,2018) ${ }^{[5]}$. Another part of scholars hold the opposite view: large-scale enterprises face greater pressure on the performance expectation of the market, so that they have greater motivation for earnings management; large-scale firms have an incentive to manipulate earnings management to reduce political costs (Li Zengfu et al.,2011) ${ }^{[6]}$.

There is no final conclusion on whether scale affects real earnings management in academic fields, and how it affects corporate financial theory remains a mystery to be solved (Ji Maoli and Li Xin, 2016) ${ }^{[7]}$. To sum up, this paper proposes the second hypothesis:

$\mathrm{H} 2$ : Scale effect moderates the relationship between real earnings management and firm value, that is, scale will inhibit the negative impact of real earnings management on firm value.

\section{Research design}

\subsection{Sample selection}

This paper selected A-share listed companies in Shanghai and Shenzhen stock exchanges from 2012 to 2016 as research samples, and did the following processing: (1) according to the industry classification of China Securities Regulatory Commission 2012 edition, financial companies and ST companies are excluded;(2) eliminate the sample data of listing and delisting in this period;(3) the data in this paper are from CSMAR database;(4) for all continuous variables, $1 \%$ quantile upper two-sided tailing is used. Stata16.0 is used for processing and regression analysis.

\subsection{Variable selection}

All variables are chosen according to the relevant research, and Table 1 showed the description and definition.

Table 1 Variable definition

\begin{tabular}{cc}
\hline Symbols & Variable definition \\
$\boldsymbol{t} \boldsymbol{b q} \boldsymbol{t}$ & Enterprise value \\
$\boldsymbol{R E} \boldsymbol{M}$ & Real earnings management \\
$\boldsymbol{D} \boldsymbol{A}$ & Accrual earnings management \\
IDR & Independent directors in board ratio \\
FSET & First shareholder's shareholding ratio \\
SEG & Number of subsidiaries companies \\
Dual & Duality \\
Big4 & Whether audited by Big4 \\
State & Equity of the enterprise \\
LEV & Total liabilities/Total assets \\
$\boldsymbol{R O A}$ & Enterprise net profit/average total assets \\
Growth & The growth rate of business revenue \\
$\boldsymbol{R O C}$ & Free cash flow/operating income \\
IN $\boldsymbol{N}$ & Year-end inventory/total assets \\
Size & Logarithm of total assets \\
\hline
\end{tabular}

\subsection{Model construction}

In order to test $\mathrm{H} 1$ and $\mathrm{H} 2$, multiple regression models are as follows:

$$
\begin{gathered}
t b q_{i, t}=\alpha_{0}+\alpha_{1} R E M(D A)_{i, t}+\sum \text { Controls }+\sum \text { year }+ \\
\sum \text { industry }+\varepsilon \\
\text { tbq } q_{i, t}=\alpha_{0}+\alpha_{1} R_{E M_{i, t}}+\alpha_{2} R E M \times \text { Size }_{i, t}+ \\
\sum \text { Controls }+\sum \text { year }+\sum \text { industry }+\varepsilon
\end{gathered}
$$

\section{Empirical results and analysis}

\subsection{Descriptive statistics}

Table 2 shows the descriptive statistical results of the main variables in this paper. The base period TBQ value of the explained variable enterprise value is 8.087 , the minimum is only 0.915 , the average value is 2.100 , and the standard deviation is 1.298 , which indicates that there is a great difference between the enterprise value of the sample companies and there are more low value enterprises. The maximum value of real earnings management rem is 0.425 , the minimum value is -1.061 , and the average value is 0.140 , which indicates that the degree of earnings management of sample companies is not the same, and there are more negative earnings management behaviors. Accrual earnings management DA also shows the same result.

Table 2 descriptive statistics

\begin{tabular}{lccccc}
\hline & $\mathrm{N}$ & mean & $\mathrm{sd}$ & $\min$ & $\max$ \\
\hline tbq0 & 4,956 & 2.100 & 1.298 & 0.915 & 8.087 \\
REM & 4,956 & -0.140 & 0.239 & -1.061 & 0.425 \\
DA & 4,956 & 0.0840 & 0.295 & $1.84 \mathrm{e}-05$ & 17.53 \\
IDR & 4,956 & 0.372 & 0.0525 & 0.333 & 0.571 \\
FSET & 4,956 & 0.985 & 0.0582 & 0.667 & 1 \\
Dual & 4,956 & 0.223 & 0.416 & 0 & 1 \\
SEG & 4,956 & 18.58 & 21.81 & 1 & 140 \\
Big4 & 4,956 & 0.0609 & 0.239 & 0 & 1 \\
State & 4,956 & 0.437 & 0.496 & 0 & 1 \\
LEV & 4,956 & 1.348 & 0.944 & 0 & 7.189 \\
ROA & 4,956 & 0.0496 & 0.0403 & -0.0521 & 0.342 \\
Growth & 4,956 & 0.164 & 0.336 & -0.503 & 11.71 \\
ROC & 4,956 & 0.0748 & 0.814 & -27.50 & 19.60 \\
INN & 4,956 & 0.171 & 0.167 & 0 & 0.940 \\
Size & 4,956 & 22.31 & 1.247 & 20.22 & 26.27 \\
\hline
\end{tabular}

\subsection{The empirical results and analysis}

Real earnings management and enterprise value regression results are shown in Table 3 . The current real earnings management (REM) t-value is -3.89 , and its three consecutive years of deferred t-value is $-3.19,-4.89$ and - 
5.58 , which are significantly negatively correlated at the gradually increasing. level of $1 \%$, and the degree of negative correlation is

Table 3 regression result

\begin{tabular}{|c|c|c|c|c|}
\hline & tbq0 & tbq1 & tbq2 & tbq3 \\
\hline REM & $\begin{array}{c}-6.160 * * * \\
(-3.89)\end{array}$ & $\begin{array}{c}-4.117 * * * \\
(-3.19)\end{array}$ & $\begin{array}{c}-6.683 * * * \\
(-4.89)\end{array}$ & $\begin{array}{c}-12.296 * * * \\
(-5.58)\end{array}$ \\
\hline IDR & $\begin{array}{c}-0.402 * * * \\
(-20.65)\end{array}$ & $\begin{array}{c}-0.250 * * * \\
(-17.83)\end{array}$ & $\begin{array}{c}-0.382 * * * \\
(-23.28)\end{array}$ & $\begin{array}{c}-0.752 * * * \\
(-26.52)\end{array}$ \\
\hline FSE & $\begin{array}{c}0.253 * * * \\
(3.59)\end{array}$ & $\begin{array}{c}0.157 * * * \\
(2.72)\end{array}$ & $\begin{array}{c}0.279 * * * \\
(4.57)\end{array}$ & $\begin{array}{c}0.530 * * * \\
(5.41)\end{array}$ \\
\hline SEG & $\begin{array}{l}0.399 \\
(1.56)\end{array}$ & $\begin{array}{l}0.026 \\
(0.14)\end{array}$ & $\begin{array}{c}0.567 * * * \\
(2.80)\end{array}$ & $\begin{array}{c}0.847^{* *} \\
(2.50)\end{array}$ \\
\hline Dual & $\begin{array}{l}-0.263 \\
(-1.34)\end{array}$ & $\begin{array}{l}0.014 \\
(0.10)\end{array}$ & $\begin{array}{c}-0.431 * * \\
(-2.48)\end{array}$ & $\begin{array}{l}0.185 \\
(0.77)\end{array}$ \\
\hline Big4 & $\begin{array}{c}0.004 * * * \\
(5.57)\end{array}$ & $\begin{array}{c}0.004 * * * \\
(7.32)\end{array}$ & $\begin{array}{c}0.004 * * * \\
(7.25)\end{array}$ & $\begin{array}{c}0.006 * * * \\
(7.05)\end{array}$ \\
\hline State & $\begin{array}{l}-0.021 \\
(-0.59)\end{array}$ & $\begin{array}{l}0.006 \\
(0.22)\end{array}$ & $\begin{array}{l}-0.010 \\
(-0.32)\end{array}$ & $\begin{array}{l}0.026 \\
(0.54)\end{array}$ \\
\hline LEV & $\begin{array}{c}0.195 * * * \\
(3.96)\end{array}$ & $\begin{array}{c}0.119 * * * \\
(3.42)\end{array}$ & $\begin{array}{c}0.225 * * * \\
(6.62)\end{array}$ & $\begin{array}{c}0.472 * * * \\
(8.05)\end{array}$ \\
\hline ROA & $\begin{array}{c}0.116^{* * *} \\
(3.61)\end{array}$ & $\begin{array}{c}0.086^{* * *} \\
(3.31)\end{array}$ & $\begin{array}{c}0.123 * * * \\
(4.21)\end{array}$ & $\begin{array}{l}0.068 \\
(1.45)\end{array}$ \\
\hline Grow & $\begin{array}{l}0.006 \\
(0.47)\end{array}$ & $\begin{array}{c}0.024 * * * \\
(3.01)\end{array}$ & $\begin{array}{l}0.010 \\
(1.00)\end{array}$ & $\begin{array}{l}-0.016 \\
(-0.76)\end{array}$ \\
\hline ROC & $\begin{array}{c}8.242^{* * *} \\
(14.68)\end{array}$ & $\begin{array}{c}7.876^{* * *} \\
(16.23)\end{array}$ & $\begin{array}{c}6.439^{* * *} \\
(13.99)\end{array}$ & $\begin{array}{c}5.645^{* * * *} \\
(8.29)\end{array}$ \\
\hline INN & $\begin{array}{l}0.032 \\
(0.74)\end{array}$ & $\begin{array}{c}0.233 * * * \\
(3.07)\end{array}$ & $\begin{array}{c}0.187 * * * \\
(4.53)\end{array}$ & $\begin{array}{c}-0.119^{*} \\
(-1.85)\end{array}$ \\
\hline Cons & $\begin{array}{l}-0.015 \\
(-0.95)\end{array}$ & $\begin{array}{c}-0.035^{* *} \\
(-2.46)\end{array}$ & $\begin{array}{l}-0.008 \\
(-0.71)\end{array}$ & $\begin{array}{l}-0.013 \\
(-0.71)\end{array}$ \\
\hline Ind & Yes & Yes & Yes & Yes \\
\hline Year & Yes & Yes & Yes & Yes \\
\hline Obs & 4,956 & 4,956 & 4,956 & 4,956 \\
\hline $\mathbf{R}^{2}$ & 0.524 & 0.522 & 0.518 & 0.529 \\
\hline
\end{tabular}

It shows that the real earnings management behavior not only damages the current enterprise value, but also damages the future enterprise value.

Accrued Earnings Management and Firm Value Regression Results. The t-value of accrual earnings management (DA) data in the current period is -0.089 , which is negatively correlated at the level of $1 \%$. However, the $t$-value of DA data for 3 consecutive years is divided into $0.070,0.131$ and -0.072 , which are inconsistent and insignificant in the direction of positive and negative signs, indicating that accrual earnings management has no impact on the future value of enterprises. In conclusion, $\mathrm{H} 1$ is verified.

\section{Additional analyses and Robustness tests}

\subsection{The empirical results and analysis}

The regression results of real earnings management, scale and enterprise value. The t-value of REM * SIZE is 3.59, and the t-values of three consecutive years are 2.72, 4.57 and 5.41 respectively, which are significantly positive at the $1 \%$ level. It shows that firm size plays a moderating role in real earnings management and firm value, which can inhibit the impact of real earnings management on firm value and reduce real earnings management behavior. $\mathrm{H} 2$ is verified.

\subsection{The empirical results and analysis}

EVA as a financial indicator to measure business performance, can overcome the defects of traditional financial evaluation system and measure the ability of enterprises to use capital to create value. Therefore, in this paper, EVA data on the market was selected as a surrogate variable for robustness analysis. The regression results of robustness test are consistent with the results of the main test, it shows that real earnings management will damage and long-term damage the value of enterprises.

\section{Conclusion}

Through the study, this paper finds that the real earnings management behavior not only affects the short-term development of the enterprise, but also has a continuous negative impact on the future value of the enterprise because of the manipulation cost and the credibility problem. Although real earnings management will produce certain adverse effect, but surely countries if you want to destroy real earnings management is not realistic, and more is not a reasonable choice, because modest real earnings management is also a important symbol of the maturity of the capital market, and a moderate amount of manipulation of real earnings management in accordance with the present laws, have no illegality. However, excessive real earnings management damages the value of enterprises and even endangers the environment of the 
capital market, which requires external laws to regulate and compress the extreme practices of real earnings management, so that the capital market can realize more effective resource allocation.

There is no conclusive conclusion on how size affects real earnings management in the academic circle. The shortcoming of this paper is that there is no in-depth study on this issue, so it is unable to explain how size of enterprises affects earnings management activities.

\section{References}

1. S.Rajgopal, R.Graham and R.Harvey. The Economic Implications of Corporate Financial Reporting [J]. JAE, 40, 3-73(2005).

2. Gao Lei, Wu Peng and Gu Tingting. Business Strategy, Market Competition and Earnings Management [J]. CMS, 09, 401-424(2015).
3. A.GUNNY. The Relation Between Earnings Management Using Real Activities Manipulation and Future Performance: Evidence from Meeting Earnings Benchmarks [J]. CAR, 27, 855-888(2010).

4. Cai Chun, Li Ming and He hui. Constraint conditions, IPO earnings management and corporate performance $[\mathrm{J}]$. AR, 10, 35-42(2013).

5. M.Cristhian, R. Jory and N. Ngo. Real Activities Manipulation and Firm Valuation [J]. RQFA, 50, 126(2018).

6. Li Zengfu, Dong Zhiqiang and Lian Yujun. Accruals Earnings Management or Real Activity Earnings Management? [J]. Management of World, 208, 129142(2011).

7. Ji Maoli and Li Xin. Research on the Influence of Real Earnings Management on Enterprise Value Based on the Empirical Analysis of Time Dimension [J]. Accounting communication, 12, 57-60(2016) 